\title{
The Relationship between Total Production and Public Spending in Mexico: Keynes versus Wagner
}

\author{
Isaac Sánchez-Juárez ${ }^{1}$, Rosa M. García Almada ${ }^{1}$ \& Héctor Barajas Bustillos ${ }^{1}$ \\ ${ }^{1}$ Department of Social Sciences, Universidad Autónoma de Ciudad Juárez, Chihuahua, México \\ Correspondence: Isaac Sánchez-Juárez, Economics’ program, Universidad Autónoma de Ciudad Juárez, Building B, \\ Chihuahua, México. Tel: 52-656-688-3835.
}

Received: November 25, 2015

doi:10.5430/ijfr.v7n1p109
Accepted: December 11, $2015 \quad$ Online Published: December 29, 2015

URL: http://dx.doi.org/10.5430/ijfr.v7n1p109

\begin{abstract}
This paper studies the relationship between public spending and production in Mexico. It aims to assess the direction of causality between these two variables ranging from economic growth to public expenditure (Wagner hypothesis) or public spending to economic growth (Keynesian hypothesis). Annual time series for the period 1925-2014 of production and public spending in real terms (1970 based) and logarithms were used. The test method involved three steps: 1) unit root tests; 2) cointegration test of Engle and Granger and 3) evidence of causality in the Granger sense. The paper uses five different specifications recommended by the specialized international literature. It was found that the series are stationary with regards first differences and are cointegrated, so we can say there is a long-term relationship. Statistical tests of Granger causality indicated that the Wagner hypothesis does not hold, while the Keynes hypothesis is validated. The study concludes that public spending and its proper management is one of the keys to promoting economic growth in Mexico. Originality/value: Time series for a long-term period, based on official information, something not done previously, were developed. This allowed the results to be more reliable than those presented by other authors. In addition, a modern procedure of econometric estimation, allowing the assessment of the two proposed scenarios was used. The work is relevant in terms of the design of economic policy and the pursuit of development in Mexico.
\end{abstract}

Keywords: Wagner hypothesis, Keynes, government expenditure, economic growth, Mexico

\section{Introduction}

This article examines the relationship between economic growth and public spending, a subject largely assessed by many international researchers (see Bergh \& Henrekson, 2011), which has relevance in terms of economic policy and welfare. Specifically, what is being sought is to assess the validity of the empirical Wagner hypothesis (WH), according to which between the variables above there is a direction of causality running from production to public spending, this with data of the Mexican economy for the period 1925-2014.

For Wagner, the expansion of public spending is the result of economic development and never vice versa. If an economy has rising government spending, the cause should seek in the improvement of revenues (product) of a nation (demand). A growing economy receives pressures from society in favor of an increase in public spending, for at least two reasons: 1) the more a society grows, becoming more developed, becoming complex, generating a greater number of conflicts, this requires greater involvement of the government, which should regulate these behaviors and seek solutions; and (2) the goods and public services are upper and elastic with respect to income (product), which means that their income elasticity is greater that unit, small changes in the income of persons lead to major changes in their demand (Magazzino, 2012: 891).

The WH contradicts the Keynes hypothesis $(\mathrm{KH})$, according to which, both during a recession and economic boom, fiscal policy (particularly public investment spending) is a desirable instrument, since it strengthens economic activity. For those who are part of this paradigm, public spending is what determines national production, through the Keynesian multiplier.

This is related to an old debate on the economy between the so-called classical and Keynesian economists. For the first the economy, operating under the free forces of the market, that is, without State intervention, reaches equilibrium, by the automatic settings that are observed in the different markets. To Keynesians, given that there are 
rigidities in the markets, particularly in labor, there is no way to achieve a long-term balance and therefore the State should intervene by means of fiscal policy to mitigate recessions and expand the moments of prosperity.

That is, there are two visions of the economic relationship between government expenditure and total production; on the one hand the Keynesians, for whom the direction of causality goes public expenditure to the product and the Wagnerians, for whom the causality runs in the opposite direction. The debate has to be clarified, since what is being discussed is whether the government should intervene in the economy to control short-term fluctuations and even being more demanding, interested in the impact of public expenditure on economic growth and therefore on the behavior of the long-term economy.

Studying above is of vital importance in the pursuit of growth as reported about the role that the government can have in stimulating the economy via increases or reductions in spending. If persistent is that product depends on government spending, or that it is caused by the latter, then an expansionary fiscal policy aimed at generating dynamism must be set especially in the short term; it would be desirable to intervene to correct the cycle. Conversely, if the direction of causality runs from the product increases to government expenditure, then the conclusion is completely different, since determinants of growth other than those laid down should be investigated here and the interest of policies should focus on them.

In short, it is interesting to highlight the sense of the relationship between production and public spending. To discover whether what has been presented is a statistical causality of government spending on production or the reverse, the first case is the $\mathrm{KH}$, while the second is the $\mathrm{WH}$. To analyze the above, two research questions were raised: is there cointegration between series of production and public spending? If the answer is yes, then what is the direction of statistical causality between series production and public spending? In addition, two additional hypotheses were raised: 1) no relationship exists between the series of production and public spending (neutrality hypothesis) and 2) there is a two-way causation between the series of government spending and production (feedback effect that emerges from some historical studies, particularly Cárdenas, 2015).

The discussion is relevant to Mexico, as a series of economic reforms have been implemented, especially fiscal, seeking increase the revenue via taxes and by the expenditure side a rule of structural balance has been created, all this with the intention of increasing the degree of intervention in the economy to correct the current stage of economic stagnation. The results presented are intended to serve to assess the performance of economic policy makers aimed at encouraging economic growth, a key part of welfare in Mexico.

Depending on what has been established, in the first part is a brief presentation of the studies that have been addressed in the discussion, both at the national and international levels. The second part makes reference to the econometric method, which involves time series and analysis of three stages: evidence of unit roots, cointegration, and the Granger causality test. The third presents the data used, the source and its characteristics. The fourth presents the results of the econometric analysis. After reviewing the theoretical arguments made by other authors and exposing the findings for the Mexican economy, the study concludes with the final part and makes some recommendations for those who have the responsibility to take decisions.

\section{Literature Review}

Since its inception the WH (Wagner, 1889 and 1904) has generated a huge amount of literature on the subject; some classical studies are by Peacock and Wiseman (1961), Gupta (1967), Goffman (1968), Musgrave (1969), Bird (1971), and Michas (1975). Subsequent to these, a great amount of work has been published; in order to examine the best way to address the issue in the Mexican case, what was done was to select those that were considered most relevant, based on those found in national and international evidence. The search revealed that there are relatively few publications for the Mexican case, at least in scientific journals, and hence the importance of the proposal.

The review starts with Henrekson (1993), who establishes that there are numerous studies that have tested the WH using time series, but finds that their results are spurious since the variables are not stationary in levels and the variables are not cointegrated. In his study, data was used from the Swedish economy for the period 1861-1990, which is long enough and it allows you to avoid many mistakes on the estimate. His study variables are public expenditure and national income.

According to Henrekson (1993:407), for Wagner there were three reasons why as an economy develops there is an increase in public spending. First, because modernization and industrialization by definition leads to an increase of private activities that transfer to the public sphere. To become more complex, society develops the need for protection and regulation by the public sector; in addition, urbanization, and the division of labor that accompanies industrialization require higher costs for the fulfillment of contracts, ensuring the order and the efficient functioning 
of the economy. Economic development becomes necessary for the increase of public activities.

Second, Wagner argued that growth in real incomes would facilitate the relative expansion of elasticity of expenditures on cultural property income and well-being. Education and culture are areas that Wagner believed were better provided by the public sector (Henrekson, 1993:407). Thirdly, for Wagner, changes in technology and economic development implied that the government took the administration of natural monopolies to strengthen economic efficiency. In fact, there are studies that by their magnitude cannot be made by the private sector, must necessarily have the support of the State; think, for example, about the construction of roads, railways, and airports, among others (Henrekson, 1993:407).

Henrekson (1993:408) concludes therefore that the WH refers to a growth of government in relation to the total economy growth as per capita national income. So to estimate the relationship we can use the following equation:

$$
\frac{G}{G D P}=f\left(\frac{G D P}{N}\right)
$$

where $G$ represents government spending, $N$ is the population, $G D P$ is the production (in real terms). Thus, if $G / G D P$ increases as $G D P / N$, then, this means the value of the elasticity of the relation exceeds zero. This was the method he used in his study, for the series analyzes the presence of unit roots and sought after if the series were cointegrated. His findings were that series were stationary at first differences and were not cointegrated, concluding that the relationship there is not between per capita production series and the share of public expenditure in the economy. The main criticism of his work is that it suggests that what happens in Sweden can be used as definitive evidence against the WH and to discredit the results of other studies that have used time series.

Several years later Peacock and Scott (2000) made a summary of the evidence up to that time, finding that the majority of studies have bad specification problems, since the WH omitted the role of public enterprises. In their opinion, most of the work is too focused on econometrics and the sophistication of its methods, more in the context of the law and its historical importance. Its recommendation is study all the public sector and its growth, not only the variable of spending, as well as consider the temporal context, socio-economically occurring all the time. Their work reflects on one of the major shortcomings of the current econometric work: economic history.

The WH can be used as a resource for analyzing the impact of changes in the pattern of a country's development on the participation of the government in economic activity, which is argued by Tobin (2005) in the case of the Chinese economy and its more or less recent economic liberalization process. Using data for the period 1978-2001, an autoregressive model and a partial adjustment model were applied and it was found that real GDP actually has a positive effect on government spending. Their results led him to conclude that the increase in the role of the State in the economy is a necessary complement to modernization. In his opinion there is no crowding-out effect of private investment.

Akitoby et al. (2006) presented an innovative study that takes into account both the short and the long term in the study of the relationship between public spending and production, using a model of correction of error for a sample of 51 developing countries. They found that the product and government spending are cointegrated in at least $70 \%$ of the countries, involving a long-term relationship in line with the $\mathrm{WH}$, which contrasts with the existing literature that provides a weak support for the $\mathrm{WH}$ in developing countries. This last statement is true if it is considered that for the Chinese case Huang (2006) didn't find evidence of the WH, the same as Narayan et al. (2008), but this was contradicted by the work of Mohammadi et al. (2008) who found that the HW is valid for the case of Turkey using an autoregressive distributed lags model.

Supporting evidence of the WH in the case of developing countries is also given by Avella (2009) who focused on Colombia. In his work the evolution of expenditure is discussed, in general terms, in the light of the political context and the demands of budgetary institutions - the study is historical-statistical in nature. With information for the period 1925-2003 evidence was found for the WH; as did Sarmiento (2012) with information for the period between 1905 and 2010. Other studies that found favorable evidence for the WH in developing countries are those by Bojanic (2013) for Bolivia and Balázs \& Ajándék (2013) for Hungary.

Magazzino (2010), using information from 1960 to 2008, for the Italian case applied a battery of methods, which include ordinary minimum squares, generalized least-squares, robust ARIMAX and GARCH. As expected, there were contradictory results. Using the simple model, in which real incomes is the independent variable and real public spending as a proportion of total production is used as the dependent variable, he found a statistically significant negative sign. Analyzing the reason for this result, it appears that one possible cause is the absence of additional explanatory variables in the model estimated. His article highlights the role played by political pressures in the 
increase of the budget and the history.

In order to continue with the previous work, Magazzino (2012) used data from the Italian economy for the period 1960-2008, now studying the impact that different types of spending (interest, final consumption, income-dependent work, production and public investment subsidies) have on actual total product. What he found was a relationship of cointegration for three of the five items. Analysis in the sense of Granger causality, only found evidence for the WH for spending and passive interests in the long term and for the variable of spending dependent on income in the short term. At the end he makes some suggestions to improve estimates, of which the most important is that it should distinguish between good and bad economic times, as well as analyze the movements of short and long term income and fiscal balances. Finally, the international review highlights the work of Magazzino et al. (2015) who for a sample of countries with data from 1980 to 2013 and the European Union found that there is a two-way causality between government spending and national income in three countries; the WH is held for eight countries and the KH is maintained for four countries, while the absence of a relationship is presented with twelve countries.

For the Mexican case eleven previous studies were found, seven of which are summarized in Iñiguez-Montiel's (2010) work and three more have been added, which are summarized in Table 1.

Table 1. Overview of previous studies for the Mexican case

\begin{tabular}{|c|c|c|c|}
\hline Authors & Period & Methodology & Conclusion \\
\hline Mann & $1925-1976$ & Coefficients of elasticity of the OLS & WH negative \\
\hline$(1980)$ & $1941-1976$ & regression equations & \\
\hline \multirow{3}{*}{$\begin{array}{l}\text { Nagarajan and Spears } \\
(1990)\end{array}$} & $1925-976$ & \multirow{3}{*}{$\begin{array}{l}\text { The rate of elasticity coefficients } \\
\text { the entry of the OLS regressions }\end{array}$} & \multirow[t]{3}{*}{ WH positive } \\
\hline & $1941-1976$ & & \\
\hline & $1950-1980$ & & \\
\hline Murthy & $1950-1980$ & Test for unit roots, cointegration & WH positive \\
\hline \multicolumn{4}{|l|}{ (1993) } \\
\hline Ashworth & $1950-1980$ & Test for unit roots, cointegration & WH negative \\
\hline (1994) & $1950-1988$ & & \\
\hline Hayo & $1950-1980$ & Test for unit roots, cointegration & WH negative \\
\hline \multicolumn{4}{|l|}{ (1994) } \\
\hline Murthy & $1950-1980$ & Test for unit roots, cointegration, & WH positive \\
\hline (1994) & $1950-1988$ & Error Correction Model & \\
\hline \multirow[t]{4}{*}{ Lin (1995) } & $1950-1980$ & \multirow{4}{*}{$\begin{array}{l}\text { Test for unit roots, cointegration, } \\
\text { test of no causality }\end{array}$} & WH negative \\
\hline & $1950-1990$ & & $1950-1980$ \\
\hline & & & WH positive \\
\hline & & & $1950-1990$ \\
\hline Galindo \& Cordera & $1970-2004$ & VAR model and structural change & WH negative \\
\hline \multicolumn{4}{|l|}{ (2005) } \\
\hline Iñiguez-Montiel & $1950-1999$ & Test for unit roots, cointegration, & WH positive \\
\hline (2010) & & $\begin{array}{l}\text { Error Correction Model and Granger } \\
\text { causality test }\end{array}$ & KH negative \\
\hline Rodríguez, et al. & $1950-2009$ & VAR model, structural change and & WH positive \\
\hline$(2013)$ & & Grang & \\
\hline Rodríguez \& & $1980-2007$ & Data panel, unit roots and & WH positive \\
\hline López-Herrera & & cointegration & \\
\hline (2014) & & & \\
\hline
\end{tabular}

Source: Expanded from the work of Iñiguez-Montiel (2010:888). 
Evidence for the Mexican case is divided into three groups; one includes the work of Mann (1980) and Nagarajan and Spears (1990), with information for the period 1925-1976. The second includes the studies of Murthy (1993), Ashworth (1994), Hayo (1994), Murthy (1994) and Lin (1995), with information for the period 1950-1980 and a third that includes the studies of Galindo \& Cordera (2005), Iñiguez-Montiel (2010), Rodríguez et al. (2013), as well as Rodríguez and López-Herrera (2014) with information from four periods (1970-2004, 1950-1999, 1950-2009 and 1980-2007). The last three studies are the basis of this, since the HW is proven once more, with a sample of 1925 to 2014, would be substantial evidence for the Mexican case.

Iñiguez-Montiel's (2010) work examines the relationship between government spending and national income in the period from 1950 to 1999 , uses time series and shows that the series are non-stationary and cointegrated. Using a Granger causality test it is found that GDP causes government expending, which establishes the validity of the WH. But he points out that his paper, was the first to assess the validity of the $\mathrm{KH}$ for Mexico; this is not necessarily true, since there is much previous work assessing the relevance of public expenditure, particularly on investment over growth, like Ramírez (1994), Lächler \& Aschauer (1998), Mendoza (2000), and Castillo \& Herrera (2005), as well as Galindo \& Cordera (2005).

The paper by Rodríguez et al. (2013) is distinguished by the application of a VAR model with data obtained from official national sources (previous work mostly used the international database of Summer-Heston). The work is under different specifications of the WH that is maintained and is consistent. Its main contribution is the consideration of structural change, determined in the year 1982 and the historical distinction between a period of economy with high State intervention from 1950 to 1981 and a free market economy from 1982 to 2009.

The latest work on the Mexican case was conducted by Rodríguez and López-Herrera (2014), who innovate using state-level data which demonstrates compliance with the WH for the period 1980-2007. They give econometrical evidence of unit roots and cointegration from the panel of data they use. They divided states into three sub-groups (by income levels), enabling them to identify that WH is fulfilled according to the level of development reached, particularly in the group of states listed as of average income.

The way in which the WH must be estimated could be determined from the review, something to be presented in the next section, also we can see that there is conflicting evidence on the validity of the WH realization, which is common in current economic studies to vary the temporality of the data, its source and the econometric technique used; despite this, it is considered that with this study we can increase knowledge on this subject in Mexico and give more validity to the studies presented.

The main contribution of this paper lies in the increase of the sample for the realization of long-term studies of the Mexican economy, overcoming all that has been done so far. Another is the review of the literature of the Mexican case and that we put at the disposal of readers so that they can replicate this work in the future. Also, unlike other papers, we use a unified series of production and public spending that were scattered in official sources and are available to readers who request them. Finally, the work applies an econometric technique already used by other authors to try to replicate their results with a larger sample and avoid creating confusion in relation to the validity (or not) of the HW (and thus of complementary as the Keynes, neutrality and feedback hypothesis).

\section{Methodology}

Following the work of Henrekson (1993) we estimated five different versions of the WH, the first already presented in the previous section, the other four are as follows, starting with the version used by Peacock and Wiseman (1961) and Musgrave (1969) (it should be noted that the KH and other hypothesis given in the introduction are evaluated to carry out the causality test):

$$
G=f(G D P)
$$

Version of Gupta (1967) and Michas (1975):

$$
\frac{G}{N}=f\left(\frac{G D P}{N}\right)
$$

Version of Mann (1980):

$$
\begin{aligned}
& G=f\left(\frac{G D P}{N}\right) \\
& \frac{G}{G D P}=f(\mathrm{GDP})
\end{aligned}
$$


Economic theory (Keynes versus Wagner hypothesis)

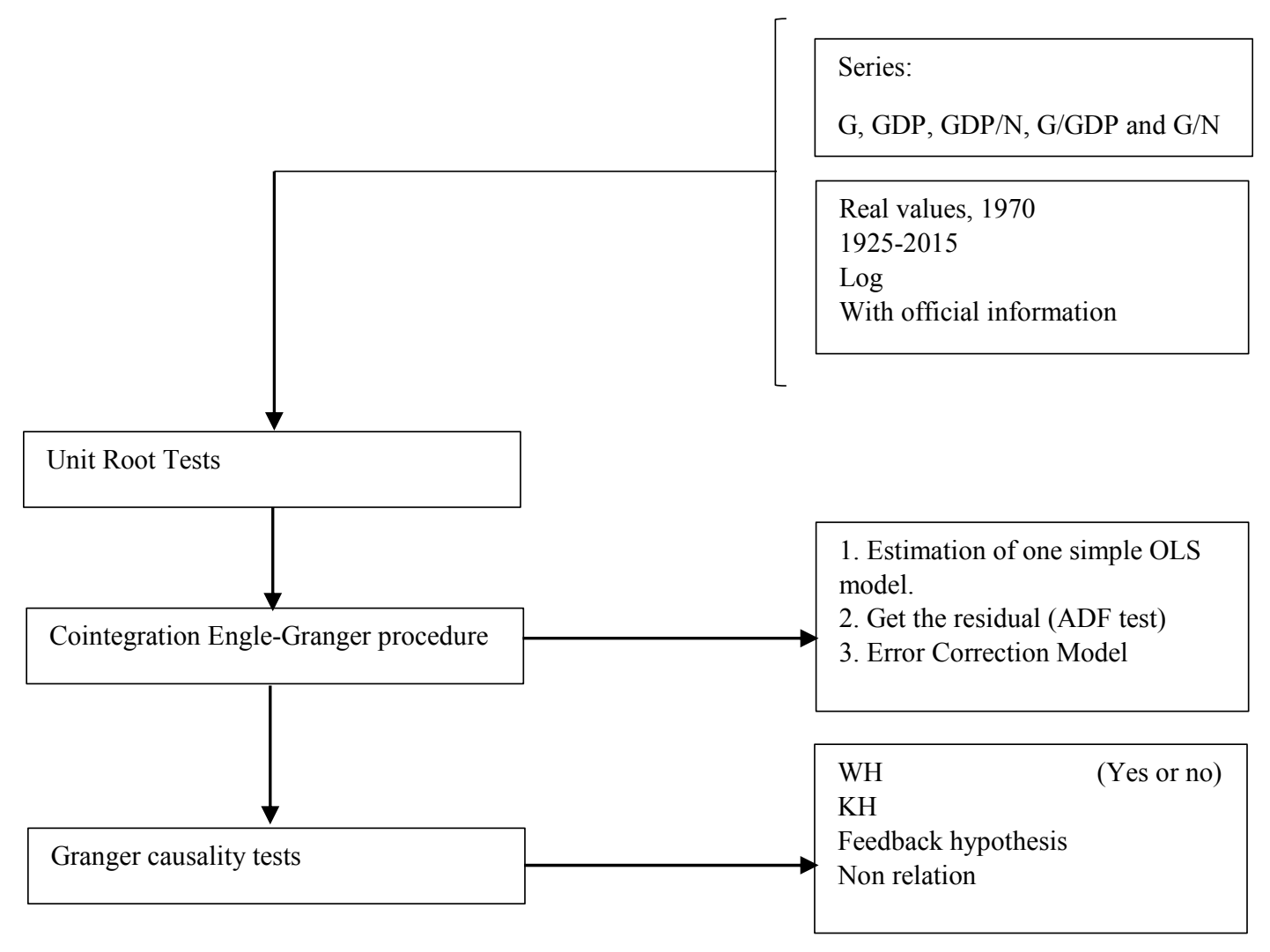

Conclusions and economic policy

Figure 1. Processes carried out in the research (methodology)

Source: Own elaboration

The examination of these economic relations was carried out with annual time series for a period of 90 years (1925-2014), using logarithms and actual values based on 1970. The analysis followed a three-stage process. First of all, the presence of unit roots was analyzed to verify whether or not the series in levels was stationary. If the variables are stationary, then the classical econometric methods are sufficient, otherwise the variables have unit root that is either not stationary or integrated first-order condition that must be fulfilled to carry out the next stage which consists of the analysis of cointegration. In the study to assess the presence of unit roots we carried out the Augmented Dickey-Fuller (ADF) test for models without trend and constant, with constant and constant and trend in levels and first differences.

The second step was to verify if there is cointegration of the series through the procedure of Engle and Granger in two stages, in order to confirm that there is a long-term relationship between the variables of interest and to examine their short-term dynamics. The economic interpretation of such a relationship is that although two variables may tend to have wandering values in time without returning to the medium constant, economic forces do not permit these series to move erratically on a permanent basis (Iñiguez-Montiel, 2010: 889). The procedure initially estimated a model through Ordinary Least Squares (OLS), from which, if the estimated residual series is stationary, it is said there is cointegration and that between the variables exists a long-term relationship.

The second stage of the procedure of Engle-Granger consists of an estimation of an Error Correction Model (ECM) to analyze the short-term relationship between the variables. An ECM combines long term with an adjustment mechanism of short term (error correction), which allows you to see how the variables vary from one period to another in search of their convergence to the balance of long term.

According to Engle and Granger, if two variables are I (1) and they are cointegrated, then there should be bi-directional or unidirectional causality in the variables I (0), therefore the third stage consisted in analyzing the 
direction of causality, using the procedure proposed by Granger to decide whether it is government expenditure that causes statistically production $(\mathrm{KH})$ or production causes statistically to the public expenditure (WH) (for a detailed explanation of the methodology see Asteriou and Hall, 2006).

\section{Data and Description}

The series of national production, population and total public expenditure were used for testing the hypotheses. The information corresponds to the Mexican economy for the period 1925-2014 values real basis of 1970. Logarithms to the series were obtained to have a better representation of their behavior. For so long it was complicated getting series since the bases that are expressed are different and have changed forms of calculation, so we proceeded to perform a series of approximations. The national production information was obtained from 1925 to 1970 of the Sistema para la Consulta de las Estadísticas Históricas de México 2014 of the Instituto Nacional de Estadística y Geografía (INEGI) at 1970 prices. To obtain information from 1970 to 1993 we turned to the same source, but 1980 prices, so we calculate the growth rates for those years and with them the missing values with 1970 prices. Data for 1993-2014 were obtained from the Banco de Información Económica (BIE) from INEGI and the procedure explained above is followed.

The population was used to calculate the values per capita in the series of interest (production and public spending). Information from 1925 to 1970 was obtained from the Sistema para la Consulta de las Estadísticas Históricas de México 2014 from INEGI, and to project values from 1970 to 1990 we used the data of the censuses of population for those years. Information for 1990 to 2014 was obtained from the projections made by the Consejo Nacional de Población (Conapo).

Public expenditure for the period 1925-1979 was obtained from the Sistema para la Consulta de las Estadísticas Históricas de México 2014 from the total of expenses; given that the data of 1972 was absent we used the same source but used the value corresponding to the total expenditure of the federal government according to administrative classes. For the period 1980-2012 we used another basis of expenditure contained in the Sistema para la Consulta de las Estadísticas Históricas de México 2014, for which growth rates were calculated, and with these the first series was completed. Data for 2013 and 2014 was obtained from BIE and followed the procedure described above.

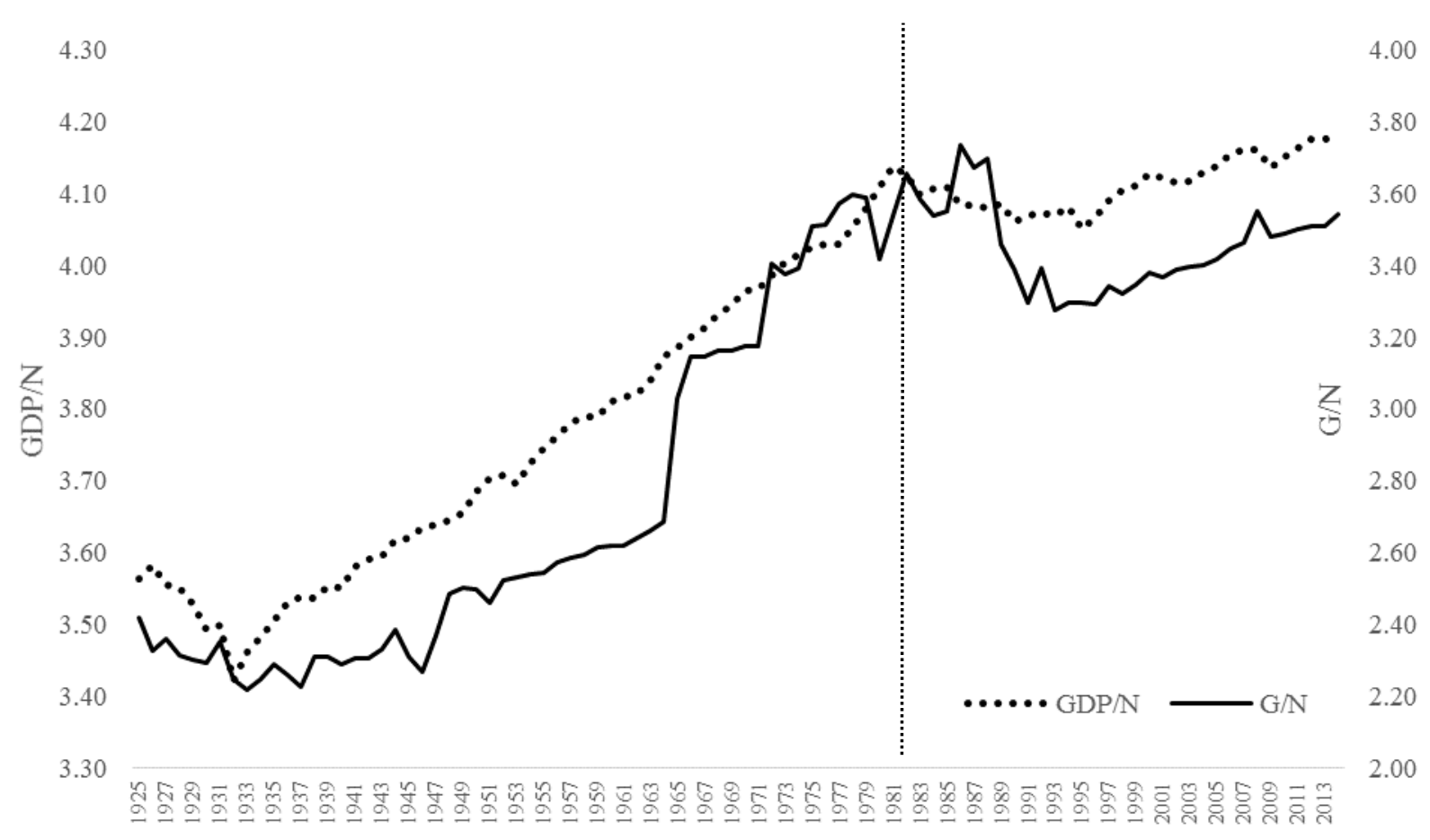

Figure 2. Evolution of G/N and GDP/N in Mexico, 1925-2014

Source: Own elaboration. 
The Mexican economy has experienced, during the study period, by at least three models of development: 1) formation of the national State from 1925 to 1939, 2) model of economic growth via industrialization with strong State intervention, 1940-1981 and 3) model of openness and macroeconomic stabilization, 1982-2015. In the economic history of Mexico, there are, according to the literature, at least two points of structural change in the sample, one in 1940 and one in 1982 (see Moreno-Brid and Ros, 2009; Cárdenas, 2015). The first is due to the start of the consolidation of the national State, the second to the debt crisis that forced a change of the economic model, one less interventionist and liberal vocation that focused on macroeconomic stability, particularly the control of inflation to the detriment of economic growth.

From Figure 2 it can be inferred that in terms of economic growth, the period 1940-1981 is superior to the period 1982-2014, in fact it confirms with the data of Table 2 (on average for the first period the economy grew $6.4 \%$ and in the second $2.12 \%$, a similar situation is observed in the case of public expenditure). With the preliminary information presented there appears to be evidence the variables are closely related and have a tendency for growth (product of public expenditure elasticity was 1.90 from 1940-1981, 1.47 from 1981-2014 and 1.71 for the whole sample). From the data inspection, we can say that series are not stationary in average and there is possible cointegration.

Table 2. Basic statistics of series, Mexico, 1925-2014

\begin{tabular}{|c|c|c|c|c|c|c|c|c|c|c|c|c|}
\hline \multirow[t]{3}{*}{ Period } & \multicolumn{3}{|c|}{$\begin{array}{c}\text { Formation of the national } \\
\text { State }\end{array}$} & \multicolumn{3}{|c|}{$\begin{array}{c}\text { Industrialization with State } \\
\text { intervention }\end{array}$} & \multicolumn{3}{|c|}{$\begin{array}{c}\text { Model of openness and } \\
\text { macroeconomic stabilization }\end{array}$} & \multicolumn{3}{|c|}{ Total period } \\
\hline & \multicolumn{3}{|c|}{$1925-1939$} & \multicolumn{3}{|c|}{$1940-1981$} & \multicolumn{3}{|c|}{$1982-2014$} & \multicolumn{3}{|c|}{$1925-2014$} \\
\hline & GDP & G & $\mathrm{G} / \mathrm{GDP}$ & GDP & G & G/GDP & GDP & G & G/GDP & GDP & G & G/GDP \\
\hline $\mathrm{N}$ & 15 & 15 & & 42 & 42 & & 33 & 33 & & 90 & 90 & \\
\hline Mean (\%) & 1.73 & 0.61 & & 6.40 & 12.19 & & 2.12 & 3.12 & & 4.08 & 7.01 & \\
\hline Median & 3.31 & -1.07 & & 6.53 & 6.11 & & 2.80 & 3.23 & & 4.44 & 4.82 & \\
\hline Standard des. & 6.99 & 12.26 & & 2.52 & 24.43 & & 3.11 & 16.72 & & 4.31 & 20.66 & \\
\hline $\begin{array}{l}\text { Product of public } \\
\text { expenditure } \\
\text { elasticity }(\%)\end{array}$ & & & 0.35 & & & 1.90 & & & 1.47 & & & 1.71 \\
\hline
\end{tabular}

Source: Own elaboration.

\section{Econometric Results}

Table 3 presents the results of the Augmented Dickey-Fuller (ADF) test for unit roots for series production, public expenditure, public expenditure per capita, public spending as a proportion of GDP and GDP per capita. The conclusion is that series are not stationary in levels; they are integrated in the order of 1 , so in their first differences are stationary. In this way it is possible to conduct a cointegration test with the five specifications presented before.

Table 3. Unit root test Augmented Dickey-Fuller (ADF), Mexico, 1925-2014

\begin{tabular}{|c|c|c|c|c|c|c|}
\hline \multirow[t]{3}{*}{ Variable } & \multicolumn{6}{|c|}{$\mathrm{ADF}$} \\
\hline & \multicolumn{2}{|c|}{ WCT } & \multicolumn{2}{|c|}{$\mathrm{C}$} & \multicolumn{2}{|l|}{$\mathrm{TC}$} \\
\hline & Statistic & Lag & Statistic & Lag & Statistic & \\
\hline GDP & 5.139 & 1 & -0.683 & 0 & -0.433 & 0 \\
\hline $\mathrm{D}(\mathrm{GDP})$ & -1.149 & 5 & -8.080 & $\mathbf{0}$ & -8.062 & $\mathbf{0}$ \\
\hline G & 2.721 & 0 & -0.508 & 0 & -1.336 & 0 \\
\hline $\mathrm{D}(\mathrm{G})$ & -8.632 & $\mathbf{0}$ & -9.436 & 0 & -9.393 & 0 \\
\hline GDP/N & 3.608 & 0 & -0.515 & 0 & -1.133 & 0 \\
\hline $\mathrm{D}(\mathrm{GDP} / \mathrm{N})$ & -7.752 & $\mathbf{0}$ & -8.669 & $\mathbf{0}$ & -8.619 & $\mathbf{0}$ \\
\hline $\mathrm{G} / \mathrm{N}$ & 1.465 & 0 & -0.646 & 0 & -1.558 & 0 \\
\hline $\mathrm{D}(\mathrm{G} / \mathrm{N})$ & -9.124 & $\mathbf{0}$ & -9.384 & $\mathbf{0}$ & -9.332 & $\mathbf{0}$ \\
\hline G/GDP & 0.402 & 0 & -1.137 & 0 & -2.036 & 0 \\
\hline $\mathrm{D}(\mathrm{G} / \mathrm{GDP})$ & -9.735 & $\mathbf{0}$ & -9.765 & $\mathbf{0}$ & -9.711 & $\mathbf{0}$ \\
\hline
\end{tabular}

Statistics in bold indicate a rejection of the null hypothesis of unit root existence. Critical values at $1 \%$ are -1.94 without constant and tendency (WCT); -2.89 with constant (C) and -3.46 to the model with tendency and constant.

Source: Own elaboration using Eviews 7.2. 
Table 4. Analysis of cointegration with Engle-Granger technique, Mexico, 1925-2014

\begin{tabular}{llllll}
\hline \multicolumn{1}{c}{ Version } & \multicolumn{1}{c}{ Constant } & $\begin{array}{l}\text { GDP o } \\
\text { GDP/N }\end{array}$ & ADF & $\mathrm{R}^{2}$ & SE \\
$\mathrm{G} / \mathrm{GDP}=\mathrm{f}(\mathrm{GDP} / \mathrm{N})$ & $\begin{array}{l}-3.189 \\
(-13.65)\end{array}$ & $\begin{array}{l}1.103 \\
(18.36)\end{array}$ & -2.910 & 0.793 & 0.135 \\
$\mathrm{G}=\mathrm{f}(\mathrm{GDP})$ & -3.590 & 1.484 & -2.563 & 0.966 & 0.147 \\
& $(-21.93)$ & $(50.43)$ & & & \\
$\mathrm{G} / \mathrm{N}=\mathrm{f}(\mathrm{GDP} / \mathrm{N})$ & -5.178 & 2.100 & -2.923 & 0.933 & 0.135 \\
& $(-22.22)$ & $(35.05)$ & & & \\
$\mathrm{G}=\mathrm{f}(\mathrm{GDP} / \mathrm{N})$ & -8.217 & 3.310 & -3.431 & 0.973 & 0.131 \\
& $(-36.44)$ & $(57.07)$ & & & \\
$\mathrm{G} / \mathrm{GDP}=\mathrm{f}(\mathrm{GDP})$ & -1.589 & $\mathbf{0 . 4 8 4}$ & -2.559 & 0.752 & 0.147 \\
& $(-9.70)$ & $(16.45)$ & & & \\
\hline
\end{tabular}

Values in parentheses are the t-ratios. ADF: Statistical test to check cointegration, following the Engle-Granger procedure. The critical value at $1 \%$ was -2.591 , using Eviews 7.2.

Source: Own elaboration.

The cointegration test revealed that series production and public spending are related in the long term, since test of unit roots on the levels of residuals from an estimate in its static form of the five proposed specifications indicated that they are stationary; it is worth noting that test was performed by using zero lags without constant and trend. As you can be seen in Table 4 the signs of the relationship between the variables are expected and were statistically significant.

As a second part of the cointegration test, the error-correction models were estimated for each specification, which appear in Table 5. It shows that the error correction mechanism presents the expected negative sign, which means that there are conditions to reduce the imbalance in the next period (year). On average, according to the results of all estimates, the deviations of the public expenditure with regard to its equilibrium level are corrected annually by approximately $17 \%$.

Table 5. Error Correction Model, Mexico, 1925-2014

\section{C: Constant, EC: Error Correction Mechanism}

\begin{tabular}{|c|c|c|c|}
\hline Specification & $\mathrm{C}$ & $\begin{array}{l}\text { GDP o } \\
\text { GDP/N }\end{array}$ & $\mathrm{EC}$ \\
\hline $\mathrm{dG} / \mathrm{GDP}$ & $\begin{array}{l}0.009 \\
(1.253)\end{array}$ & $\begin{array}{l}-0.592 \\
(-1.428)\end{array}$ & $\begin{array}{l}\mathbf{- 0 . 1 8 8} \\
(-3.425)\end{array}$ \\
\hline $\mathrm{dG}$ & $\begin{array}{l}0.013 \\
(1.332)\end{array}$ & $\begin{array}{l}0.549 \\
(1.392)\end{array}$ & $\begin{array}{l}\mathbf{- 0 . 1 4 1} \\
(-2.733)\end{array}$ \\
\hline $\mathrm{dG} / \mathrm{N}$ & $\begin{array}{l}0.009 \\
(1.252)\end{array}$ & $\begin{array}{l}0.399 \\
(0.963)\end{array}$ & $\begin{array}{l}\mathbf{- 0 . 1 8 8} \\
(-3.430)\end{array}$ \\
\hline $\mathrm{dG}$ & $\begin{array}{l}0.019 \\
(2.522)\end{array}$ & $\begin{array}{l}0.461 \\
(1.146)\end{array}$ & $\begin{array}{l}\mathbf{- 0 . 2 4 3} \\
(-4.404)\end{array}$ \\
\hline $\mathrm{dG} / \mathrm{GDP}$ & $\begin{array}{l}0.012 \\
(1.283)\end{array}$ & $\begin{array}{l}-0.422 \\
(1.070)\end{array}$ & $\begin{array}{l}-\mathbf{0 . 1 4 1} \\
(-2.725)\end{array}$ \\
\hline
\end{tabular}

Values in parentheses are the t-ratios. Significant corrective mechanisms to the $1 \%$

Source: Own elaboration using Eviews 7.2. 
At this point, we know that series are non-stationary in levels and are cointegrated, as far as we know there is a relationship between them - what we don't know is the direction of causality of the same. We have, in accordance with economic theory, two hypotheses that might respond to the type of relationship, the $\mathrm{WH}$ and the $\mathrm{KH}$. To verify which applies in the case of the Mexican economy we conducted a Granger statistical causality test, with the results of Table 6. Using ten lags (and even with 25 lags that are not reported) the result is that the WH is discarded while the KH is held. This result was not expected, but coincides with the findings of other researchers. Thus, fiscal policy, particularly public expenditure, has been partly responsible for the observed trajectory of economic growth in Mexico.

Table 6. Granger causality test, Mexico, 1925-2014

\begin{tabular}{llll}
\hline \multicolumn{1}{c}{ Direction of causality } & F -statistical & Probability & \multicolumn{1}{c}{ Inference } \\
& & & WH \\
GDP/N does not cause G/GDP & 1.176 & 0.325 & negative \\
G/GDP does not cause GDP/N & 2.017 & 0.047 & KH positive \\
& & & WH \\
GDP does not cause G & 1.405 & 0.200 & negative \\
G does not cause GDP & 2.238 & 0.027 & KH positive \\
& & & WH \\
GDP/N does not cause G/N & 1.410 & 0.198 & negative \\
G/N does not cause GDP/N & 1.918 & 0.060 & KH positive \\
& & & WH \\
GDP/N does not cause G & 1.607 & 0.126 & negative \\
G does not cause GDP/N & 1.905 & 0.062 & KH positive \\
& & & WH \\
GDP does not cause G/GDP & 1.051 & 0.413 & negative \\
G/GDP does not cause GDP & 2.241 & 0.027 & KH positive \\
\hline
\end{tabular}

These tests were performed with 10 lags.

Source: Own elaboration using Eviews 7.2.

\section{Conclusions}

When we started the project of investigation we believed that government expenditure preceded changes in total production, and that the WH was verified for the Mexican case and in consequence should change the focus of the federal policy of promoting economic growth. The results are that the WH is not maintained, which agrees with the work of Mann (1980), Ashworth (1994), Hayo (1994), Lin (1995) and Galindo \& Cordera (2005). The result is that Keynes was right, correct fair path production and growth of an economy necessarily passes by increases in public spending, particularly those related to public investment, as different studies show (recently Srithongrung \& Sánchez, 2015).

The hypothesis of neutrality, and feedback indicated at the beginning are not verified, only the $\mathrm{KH}$, from which it is concluded that the Mexican federal government must increase its expenditure in critical times and cutting it in moments of bonanza, following a countercyclical policy. In the same way, it is recommended to increase the amount of the expenditure, without increasing taxes, taxing is only the best way for those who have more income, since of the possible sources of financing of expenditure, this is the least distorting in the long term. Not least, the authorities should make good use of the resources; you have to allocate the available capital where greater dividends are generated for a vast majority of the population; otherwise, spending could crowd-out and not supplement private investment so cancel the possibilities of growth. The Mexican federal government has already advanced in this direction by establishing the budget base zero.

From historical revision it is known for 1925 and until 1939 the Mexican economy did not have a strong government, was under construction and it is likely that the $\mathrm{WH}$ is met for that period, since the economy was growing on the 
basis of foreign investment and from here you could expand the government through its spending. From 1940 the government started its consolidation and began a period of clear intervention in the economy, through the creation of formal institutions and companies that collaborate with the national development, a situation that lasted until the beginning of the 1980s, which verifies the KH, as has been reported here. From 1982 the Mexican economy changes its course with a consolidated federal government and even bulky, according to those who took decisions back then, so they decided to modify the economic model, to give greater depth to the market forces and less to the State, which corresponds to a low economic growth, an annual average of $2.1 \%$ through 2014 as reported in Table 2 . The slow economic growth in the present day is correlated with low relative growth of public expenditure $(3.1 \%$ against $12.1 \%$ from the period 1940-1981). In this way, the KH is validated.

At the end of this report, there are some elements that are outstanding: 1) we must evaluate the $\mathrm{WH}$ and $\mathrm{KH}$ considering the identified sub-periods; 2) it is appropriate to incorporate the estimates, public spending on investment; 3 ) it is necessary to apply a different technique for the verification of cointegration, as it can be Fully Modified OLS, Canonical Cointegrating Regression or Dynamic OLS and 4) the historic approach is crucial to provide more substantive elements to the discussion. This is intended to take advantage of the long series of information that has been built. For now, with the results presented, it can be said that the effective and efficient intervention of the government in the economy is necessary, always complemented by the market and, in particular, the enterprise-class, who at the end of the story generated wealth in an economy through their daily efforts of production of goods and services for the satisfaction of needs.

\section{References}

Akitoby, B., Clemens, B., Gupta, S., \& Inchauste, G. (2006). Public spending, voracity, and Wagner's law in developing countries. European Journal of Political Economy, 22(4), 908-924. http://dx.doi.org/10.1016/j.ejpoleco.2005.12.001

Ashworth, J. (1994). Spurious in Mexico: a comment on Wagner's Law. Public Finance, 49, 282-286.

Asteriou, D., \& Hall, S. (2006). Applied econometrics. A modern approach. New York: Palgrave MacMillan.

Avella, M. (2009). El crecimiento del gasto público en Colombia, 1925-2003, ¿una visión descriptiva a la Wagner o a la Peacock y Wiseman? Revista de Economía Institucional, 11(20), 83-137.

Balázs, K., \& Ajándék, P. (2013). Economic growth and fiscal expenditures in Hungary - Stylized facts based on VAR modelling. Tér-Gazdaság-Ember, 1(3), 55-73.

Bergh, A., \& Henrekson, M. (2011). Government size and growth: a survey and interpretation of the evidence. Journal of Economic Surveys, 25(5), 872-897. http://dx.doi.org/10.1111/j.1467-6419.2011.00697.x

Bird, R. (1971). Wagner's law of expanding state activity. Public Finance, 26, 1-26.

Bojanic, A. (2013). Testing the validity of Wagner's law in Bolivia: A cointegration and causality analysis with disaggregated data. Revista de Análisis Económico, 28(1), 25-45. http://dx.doi.org/10.4067/S0718-88702013000100002

Cárdenas, E. (2015). El largo curso de la economía mexicana. De 1780 a nuestros días. Mexico: Fondo de Cultura Económica.

Castillo, R., \& Herrera, J. (2005). El efecto del gasto público sobre el privado en México. Estudios Económicos, 20(2), 173-196.

Galindo, L., \& Cordera, R. (2005). Las relaciones de causalidad entre el gasto público y el producto en México: ¿Existe evidencia de cambio estructural? Revista Mexicana de Economía y Finanzas, 4(4), 369-386.

Goffman, I. (1968). On the empirical testing of Wagner's law: a technical note. Public Finance, 23(3), 359-364.

Gupta, S. (1967). Public expenditure and economic growth: a time series analysis. Public Finance, 22, 423-461.

Hayo, B. (1994). No further evidence of Wagner's Law for Mexico. Public Finance, 49, 287-294.

Henrekson, M. (1993). Wagner's law - a spurious relationship? Public Finance, 48(2),406-415.

Huang, C. (2006). Government expenditures in China and Taiwan: Do they follow Wagner's law? Journal of Economic Development, 31(2), 139-148.

Iñiguez-Montiel, A. (2010). Government expenditure and national income in Mexico: Keynes versus Wagner. Applied Economics Letters, 17(9), 887-893. http://dx.doi.org/10.1080/13504850802599433

Lächler, U., \& Aschauer, D. (1998). Public investment and economic growth in Mexico. Policy Research Working 
Paper 1964. The World Bank.

Lin, C. (1995). More evidence on Wagner's Law for Mexico. Public Finance, 50, 267-277.

Magazzino C., Giolli, L., \& Mele, M. (2015). Wagner's law and Peacock and Wiseman's displacement effect in European Union countries: A panel data study. International Journal of Economics and Financial Issues, 5(3), 812-819.

Magazzino, C. (2010). Wagner's law in Italy: empirical evidence from 1960 to 2008. Global \& Local Economic Review, 14(1), 91-116.

Magazzino, C. (2012). Wagner versus Keynes: public spending and national income in Italy. Journal of Policy Modeling, 34(6), 890-905. http://dx.doi.org/10.1016/j.jpolmod.2012.05.012

Mann, A. (1980). Wagner's law: an econometric test for Mexico, 1925-1976. National Tax Journal, 33(2), 189-201.

Mendoza, M. (2000). La inversión privada y de gobierno en el crecimiento económico de México. Política y Cultura, (13), 169-186.

Michas, N. (1975). Wagner's law of public expenditures: what is appropriate measurement for a valid test? Public Finance, 30, 77-84.

Mohammadi, H., Cak, M., \& Cak, D. (2008). Wagner's hypothesis. New evidence from Turkey using the bounds testing approach. Journal of Economic Studies, 35(1), 94-100. http://dx.doi.org/10.1108/01443580810844442

Moreno-Brid, J., \& Ros, J. (2009). Development and growth in the Mexican economy: An historical perspective. New York: Oxford University Press. http://dx.doi.org/10.1093/acprof:oso/9780195371161.001.1

Murthy, N. (1993). Further evidence of Wagner's Law for Mexico: an application of cointegration Analysis. Public Finance, 48(1), 92-96.

Murthy, N. (1994). Wagner's Law, spurious in Mexico or misspecification: a reply. Public Finance, 49, 295-303.

Musgrave, R. (1969). Fiscal systems. New Haven and London: Yale University Press.

Nagarajan, P., \& Spears, A. (1990). An econometric test of Wagner's law for Mexico: a reexamination. Public Finance, 45, 167-178.

Narayan, P., Nielsen, I., \& Smyth, R. (2008). Panel data, cointegration, causality and Wagner's law: Empirical evidence from Chinese provinces. China Economic Review, 19(2), 297-307. http://dx.doi.org/10.1016/j.chieco.2006.11.004

Peacock, A., \& Scott, A. (2000). The curious attraction of Wagner's law. Public Choice, 102(1), 1-17. http://dx.doi.org/10.1023/A:1005032817804

Peacock, A., \& Wiseman, J. (1961). The growth of public expenditure in the United Kingdom. Princeton, NJ: Princeton University Press.

Ramírez, M. (1994). Public and private investment in Mexico, 1950-1990: an empirical analysis. Southern Economic Journal, 15(1), 1-17. http://dx.doi.org/10.2307/1060126

Rodríguez, D., \& López-Herrera, F. (2014). Desarrollo económico y gasto público de las entidades federativas en México. Análisis de cointegración en panel y la ley de Wagner. Gestión y Política Pública, 22(2), 299-330.

Rodríguez, D., Venegas-Martínez, F., \& Lima, V. (2013). La ley de Wagner versus la hipótesis keynesiana: el caso de México, 1950-2009. Investigación $\quad$ Económica, $\quad 72(283), \quad 69-98$. http://dx.doi.org/10.1016/S0185-1667(13)72587-6

Sarmiento, V. (2012). Comportamiento del gasto primario en Colombia: una evidencia empírica. Finanzas y Política Económica, 4(2), 113-126.

Srithongrung, A., \& Sánchez, I. (2015). Fiscal policies and subnational economic growth in Mexico. International Journal of Economics and Financial Issues, 5(1), 11-22.

Tobin, D. (2005). Economic liberalization, the changing role of the state and "Wagner's law": China's development experience since 1978. World Development, 33(5), 729-743. http://dx.doi.org/10.1016/j.worlddev.2004.12.001

Wagner, A. (1889). Finanzwissenschaft, Leipzig. Retrieved from https://archive.org/details/finanzwissensch00wagngoog

Wagner, A. (1904). Les fondements de l'economie politique. Paris: Girard \& Brière. 